\title{
Arima hot spring waters as a deep-seated brine from subducting slab
}

\author{
Chiho Kusuda ${ }^{1}$, Hikaru Iwamori ${ }^{2,3}{ }^{*}$, Hitomi Nakamura ${ }^{2,3}$, Kohei Kazahaya ${ }^{4}$ and Noritoshi Morikawa ${ }^{4}$
}

\begin{abstract}
Non-volcanic hot springs are generally believed to originate through circulation of meteoric or buried sea water heated at depth. In this study, we report the geochemical characteristics of the Arima and Takarazuka hot spring waters, known as Arima-type deep brine, in a forearc region of southwestern Japan. We examine 14 water samples to determine the levels of 12 solute elements or components and the isotopic ratios of $\mathrm{H}, \mathrm{He}, \mathrm{C}, \mathrm{O}$, and $\mathrm{Sr}$, and we perform correlation analysis of the data to deduce the source materials and origin of the deep brine. Moreover, we perform numerical modeling of oxygen and hydrogen isotopic fractionation along subducting slabs to examine the composition of slab-derived fluid as a possible candidate of the deep brine. The results suggest that the high salinity and solute concentrations with characteristic oxygen, hydrogen, carbon, and strontium isotope compositions, as well as high ${ }^{3} \mathrm{He} /{ }^{4} \mathrm{He}$ ratios, can be explained by a dehydrated component of the subducted Philippine Sea slab. Hence, this study may provide an invaluable understanding of geofluid processes over a significant depth range.
\end{abstract}

Keywords: Subduction; Geofluid; Slab-fluid; Hot spring; Arima

\section{Background}

Various geophysical and geochemical studies suggest that within the mantle wedge and crust in subduction zones, fluid fluxes may trigger seismicity and magmatism throughout the system (e.g., Iwamori 2007; Hasegawa et al. 2008). The term 'fluid' in this case includes a variety of physical substances such as aqueous fluid, supercritical fluid, and melt (or magma), which are often referred to as 'geofluids.' Studies on geofluids may provide a clue to understanding the hydrological budget in subduction zones, as well as the global water and element cycling, since subduction zones are the major injection sites of water and chemical elements existing at the surface into the Earth's interior (Jarrard 2003; Fischer 2008; Iwamori and Albarède 2008; Shinohara 2013).

With its distinct geochemical signatures, the Arima-type brine is known as a possible candidate of deep-seated geofluid. Despite its presence in non-volcanic regions in the forearc domain, in which Quaternary volcanoes do

\footnotetext{
* Correspondence: hikaru@jamstec.go.jp

${ }^{2}$ Department of Solid Earth Geochemistry, Japan Agency for Marine-Earth Science and Technology (JAMSTEC), 2-15 Natsushima-cho, Yokosuka 237-0061, Japan

${ }^{3}$ Department of Earth and Planetary Sciences, Tokyo Institute of Technology, 2-12-1 Ookayama, Meguro-ku, Tokyo 152-8551, Japan

Full list of author information is available at the end of the article
}

not appear (Figure 1), the oxygen and hydrogen isotope compositions have affinities to magmatic/metamorphic fluids; thus, the presence of a deep brine distinct from near-surface water, including meteoric water and seawater, has been long argued for the origin of Arima hot springs (e.g., Matsubaya et al. 1973; Tanaka et al. 1984; Masuda et al. 1985 and the references therein; overview presented in Sakai and Matsuhisa 1996). Although a precise definition of Arima-type brine has not been presented, nonvolcanic hot springs with high chlorine (approximately $40,000 \mathrm{ppm}$ ) and other solute contents, as well as the distinct oxygen and hydrogen isotopic ratios, occur in the Osaka to Kii areas, southwestern Japan, along large fault zones (Matsubaya 1981; Nishimura 2000), where high ${ }^{3} \mathrm{He} /{ }^{4} \mathrm{He}$ of gases occur associated with spring waters (Nagao et al. 1981; Sano and Wakita 1985; Okada et al. 1994; Matsumoto et al. 2003; Umeda et al. 2006; Morikawa et al. 2008).

On the contrary, the nature and composition of such deep geofluids have been studied through high-pressure experiments on element partitioning (e.g., Brenan et al. 1995; Keppler 1996; Kogiso et al. 1997; Kessel et al. 2005), geochemical constraints on subducting materials and arc magmas (e.g., Ishikawa and Nakamura 1992; Plank and Langmuir 1998; Pearce et al. 2005; Nakamura et al. 2008;

\section{实 Springer}




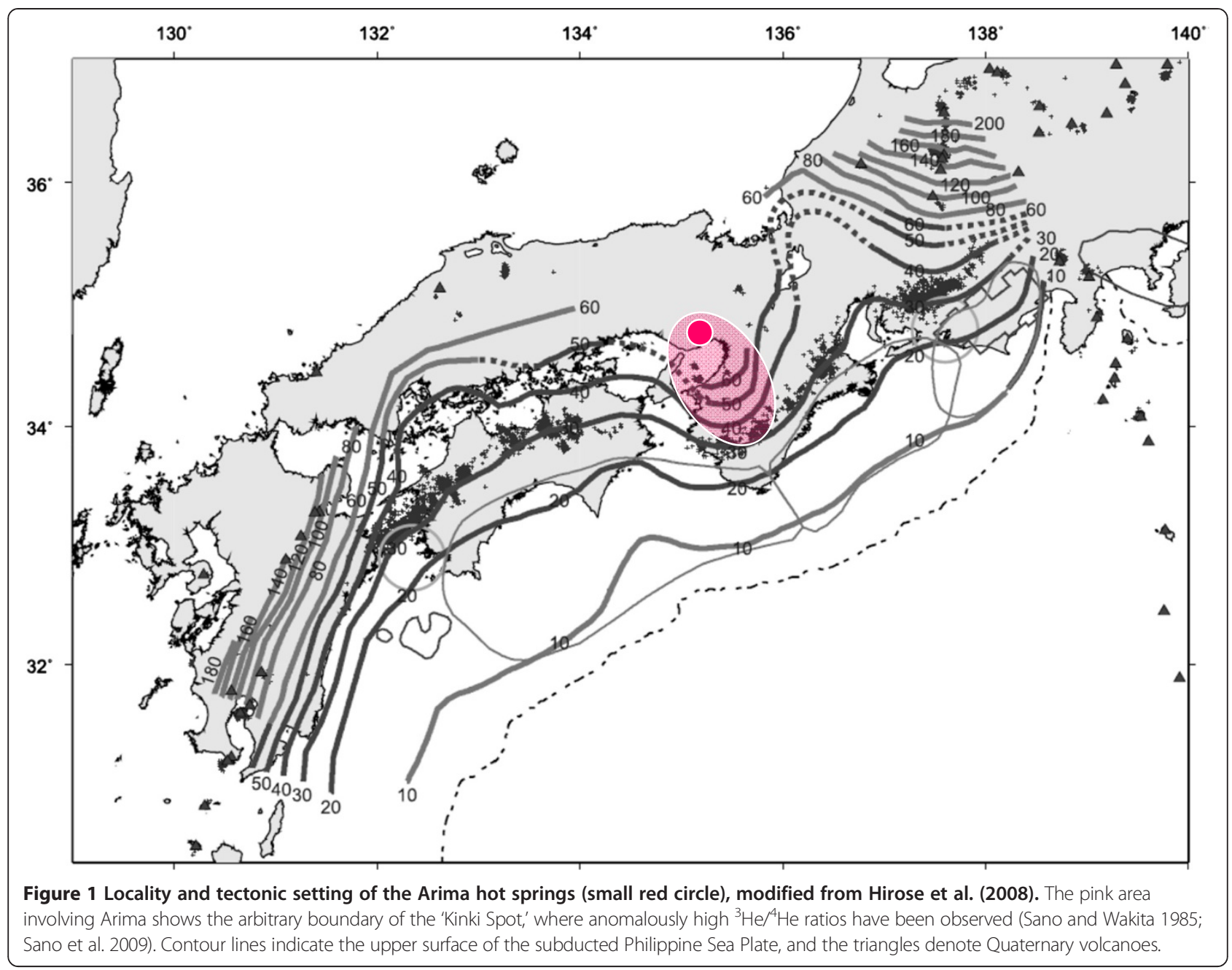

Kimura et al. 2009), and fluid inclusions in mantle-derived xenoliths (e.g., Schiano et al. 1995; Ishimaru and Arai 2008; Ionov 2010; Kawamoto et al. 2013), constraining elemental abundances and isotopic ratios of these geofluids.

In this study, we discuss the relationship between Arimatype brine and deep geofluids in a definitive manner. In particular, we examine multiple element and isotopes of the hot spring waters, including the oxygen and hydrogen isotopic composition of the slab-derived fluid, and we determine whether the characteristic $\mathrm{O}-\mathrm{H}$ isotopic compositions of the Arima-type brine are explained by the slab fluid.

\section{Multiple elemental and isotopic characterization Sample and analytical methods}

The samples and localities are listed in Table 1. In December 2007, water and gas samples were collected from hot mineral springs and artesian wells at 14 sites in the Arima area, located on the northern slope of the Rokko Mountains where basement rocks are composed mainly of Paleozoic to Mesozoic sedimentary rocks; upper
Cretaceous to Paleogene volcanic rocks, including mostly rhyolites and andesites; and Cretaceous to Paleogene granitic rocks (Arai 2007). The Arima-Takatsuki Tectonic Line and the associated faults are distributed in the studied area, along which the Arima hot spring waters flow from the surface (Kozuki 1962).

The studied area is within $600 \mathrm{~m}$ zonally and $900 \mathrm{~m}$ meridionally in Arima. In addition, two samples were obtained in Takarazuka, about $10 \mathrm{~km}$ east of Arima, where most of the springs flow naturally from shallow (40 $\mathrm{m}$ in depth) to deep $(1500 \mathrm{~m})$ reservoirs or flow paths along the faults (e.g., Kozuki 1962), with a temperature range of $19^{\circ} \mathrm{C}$ to $96^{\circ} \mathrm{C}$ (Table 1 ).

In order to acquire a multi-element and multi-isotope dataset for each sample, the following measurements and analyses were performed for the sampled solutions and gases: (1) Temperature, $\mathrm{pH}$, and electrical conductivity (EC; Table 2) of waters were conducted in situ at sampling sites. (2) Concentrations of cations and anions of water samples were determined with ion chromatography (DXi-500; Thermo Scientific Dionex, CA, USA). (3) Alkalinity, in 
Table 1 Sample and locality list

\begin{tabular}{|c|c|c|c|c|}
\hline Sample No. & Name of springs & Latitude & Longitude & Sampling date \\
\hline TW-1, TG-1 & Takarazuka Tibori & $34^{\circ} 47^{\prime} 51.66^{\prime \prime}$ & $135^{\circ} 22^{\prime} 01.32^{\prime \prime}$ & 12 December 2007 \\
\hline TW-2 & Takarazuka Spa & $34^{\circ} 48^{\prime} 20.22^{\prime \prime}$ & $135^{\circ} 20^{\prime} 13.56^{\prime \prime}$ & 12 December 2007 \\
\hline$A W-1, A G-1$ & Gosya & $34^{\circ} 48^{\prime} 12.42^{\prime \prime}$ & $135^{\circ} 12^{\prime} 51.60^{\prime \prime}$ & 13 December 2007 \\
\hline AW-2 & Tansan & $34^{\circ} 47^{\prime} 41.94^{\prime \prime}$ & $135^{\circ} 15^{\prime} 02.04^{\prime \prime}$ & 13 December 2007 \\
\hline AW-3 & Gokuraku & $34^{\circ} 47^{\prime} 46.08^{\prime \prime}$ & $135^{\circ} 14^{\prime} 57.12^{\prime \prime}$ & 13 December 2007 \\
\hline AW-4 & Uwanari & $34^{\circ} 47^{\prime} 45.96^{\prime \prime}$ & $135^{\circ} 14^{\prime} 57.12^{\prime \prime}$ & 13 December 2007 \\
\hline AW-5, AG-5 & Gosyo & $34^{\circ} 47^{\prime} 47.34^{\prime \prime}$ & $135^{\circ} 14^{\prime} 52.80^{\prime \prime}$ & 13 December 2007 \\
\hline AW-6 & Tenjin & $34^{\circ} 47^{\prime} 49.32^{\prime \prime}$ & $135^{\circ} 14^{\prime} 54.42^{\prime \prime}$ & 13 December 2007 \\
\hline AW-7 & Kosenkaku & $34^{\circ} 47^{\prime} 55.86^{\prime \prime}$ & $135^{\circ} 14^{\prime} 50.28^{\prime \prime}$ & 13 December 2007 \\
\hline AW-8 & Mint Resort Inn & $34^{\circ} 48^{\prime} 11.28^{\prime \prime}$ & $135^{\circ} 14^{\prime} 59.28^{\prime \prime}$ & 14 December 2007 \\
\hline AW-9 & Ginsuiso Ginsen south & $34^{\circ} 48^{\prime} 03.48^{\prime \prime}$ & $135^{\circ} 14^{\prime} 47.94^{\prime \prime}$ & 14 December 2007 \\
\hline AW-10 & Ginsuiso Ginsen north & $34^{\circ} 48^{\prime} 06.66^{\prime \prime}$ & $135^{\circ} 14^{\prime} 51.18^{\prime \prime}$ & 14 December 2007 \\
\hline AW-11 & Ginsuiso Kinsen & $34^{\circ} 48^{\prime} 06.42^{\prime \prime}$ & $135^{\circ} 14^{\prime} 50.88^{\prime \prime}$ & 14 December 2007 \\
\hline AW-12 & Choraku Kinsen & $34^{\circ} 48^{\prime} 12.72^{\prime \prime}$ & $135^{\circ} 14^{\prime} 49.62^{\prime \prime}$ & 14 December 2007 \\
\hline
\end{tabular}

reference to the concentration of total dissolved $\mathrm{HCO}_{3}$, was determined by titrating with $\mathrm{H}_{2} \mathrm{SO}_{4}$ up to a $\mathrm{pH}$ of 4.8. (4) Hydrogen and oxygen stable isotopes were measured by mass spectrometric analysis (Delta V advantage and Delta plus, Thermo-Fisher Scientific Inc., Bremen, Germany). $\mathrm{H}_{2}$ generated by the $\mathrm{H}_{2} \mathrm{O}-\mathrm{H}_{2}$ reduction method by $800^{\circ} \mathrm{C}$ metal chromium was applied for $\delta \mathrm{D}$ analyses, and $\mathrm{CO}_{2}$ generated by the automated $\mathrm{H}_{2} \mathrm{O}-\mathrm{CO}_{2}$ equilibration method was applied for $\delta^{18} \mathrm{O}$ analyses. (5) The stable carbon isotopic ratio $\left(\delta^{13} \mathrm{C}\right)$ of dissolved inorganic carbon (DIC), which was conventionally represented with respect to Vienna Pee Dee Belemnite (VPDB), was measured by continuous flow isotope-ratio mass spectrometry (IRMS) with a gas chromatography system (Delta-V Advantage and GasBench II, Thermo-Fisher Scientific Inc.). The detailed procedures have been described by Takahashi et al. (2013). (6) Helium and neon concentrations and the helium isotope ratios were measured with a noble gas mass spectrometer, model MM5400 (Micromass UK Ltd., Manchester, UK). Technical details of the extraction of dissolved noble gases and the mass spectrometry, including the purification procedures, have been described by Morikawa et al. (2008). (7) $\mathrm{Sr}$ concentrations were measured with an inductively coupled plasma mass spectrometer (ICPMS; ELAN DRC II, Perkin Elmer, Waltham, MA, USA) after dilution of the sample with $\mathrm{HNO}_{3}$ containing the indium internal standard. (8) Sr isotope ratios were determined with a thermal ionization mass spectrometer (TIMS; TRITON, Thermo Finnigan, Thermo-Fisher Scientific Co. Ltd., Hudson, NH, USA) after chemical separation of $\mathrm{Sr}$ using a $0.3-\mathrm{mL}$ DCTA-pyridine cation-exchange column with a procedure modified after Birck (1986). Laboratory analyses (2) to (6) were performed at the Geological Survey of Japan, AIST;
(7) and (8) were performed at the Japan Agency for Marine-Earth Science and Technology.

\section{Elemental and isotopic composition}

The results are listed in Table 2 . Both the solute concentrations and the isotopic ratios of hydrogen, helium, carbon, oxygen, and strontium exhibited wide variations. The chlorine concentration ranges from 14 to approximately $40,000 \mathrm{ppm}$ (up to twice that of seawater), the lithium concentration ranges from 0.02 to $51.90 \mathrm{ppm}(0.2$ to 300 times that of seawater), and the air-normalized ${ }^{3} \mathrm{He} /{ }^{4} \mathrm{He}$ ratio ranges from 2.33 to 7.51 (close to that of the upper mantle represented by mid-ocean ridge basalt). In order to discuss origin of the brines that may potentially involve multiple source materials and processes, analyses based on multiple element/isotope data, as shown in Table 2, are useful for clarifying, for example, the association of elements/isotopes derived from individual sources. Such multiple element/isotope studies, including hydrocarbon species, on brine or gas from various tectonic settings such as subduction zones (e.g., Mutnovsky Volcano, Kamchatka; Zelenski et al. 2012), ocean islands (e.g., Socorro Island, Mexico; Taran et al. 2010), and continental-oceanic rifts (Salton Sea, USA; Mazzini et al. 2011) have been successfully used to identify various sources. These sources include altered basaltic oceanic crust (AOC), oceanic sediment, and continental and mantle sources, and their modification by chemical and thermal processes such as mixing, serpentinization, and near-surface cooling.

The correlation matrix, in which correlation coefficients are arranged in a matrix consisting of individual elements/ isotopes to be correlated to show the correlation coefficient at their intersection cell (Figure 2), shows an overall data structure. Many of the major solute elements/ions 
Table 2 Analytical results of the Arima and Takarazuka hot spring waters and gases

\begin{tabular}{|c|c|c|c|c|c|c|c|c|c|c|c|c|c|c|}
\hline & $\begin{array}{l}\text { TW-1 } \\
\text { [TG-1] }\end{array}$ & TW-2 & $\begin{array}{l}\text { AW-1 } \\
{[A G-1]}\end{array}$ & AW-2 & AW-3 & AW-4 & $\begin{array}{l}\text { AW-5 } \\
\text { [AG-5] }\end{array}$ & AW-6 & AW-7 & AW-8 & AW-9 & AW-10 & AW-11 & AW-12 \\
\hline Temperature $\left({ }^{\circ} \mathrm{C}\right)$ & 22.3 & 25.9 & 32.1 & 19.1 & 95.3 & 88.3 & 80.3 & 88.3 & 61.5 & 33.3 & 19.4 & 19.5 & 29.2 & 32.2 \\
\hline $\mathrm{pH}$ & 6.20 & 6.47 & 6.23 & 5.30 & 6.42 & 6.65 & 6.89 & 6.38 & 6.51 & 6.04 & 5.78 & 6.51 & 5.64 & 6.00 \\
\hline $\mathrm{EC}(\mathrm{mS} / \mathrm{cm})$ & 17.72 & 62.10 & 11.79 & 0.30 & 62.80 & 57.10 & 26.40 & 63.30 & 40.40 & 42.20 & 1.85 & 4.60 & 70.80 & 67.50 \\
\hline Depth (m) & 800 & 1,500 & $n k$ & 40 & 240 & 187 & 165 & 206 & 170 & 800 & nk & $n k$ & $n k$ & nk \\
\hline$\delta^{18} 0_{\text {SMOW }}(\% 0)$ & -0.35 & 1.09 & -7.00 & -7.88 & 2.07 & 0.77 & -4.09 & 2.22 & -1.85 & -3.26 & -7.27 & -7.08 & 4.98 & 3.61 \\
\hline$\delta D_{\text {SMOW }}(\% 0)$ & -40.44 & -38.51 & -51.05 & -50.27 & -38.15 & -40.50 & -45.92 & -37.71 & -44.69 & -44.31 & -48.92 & -48.56 & -34.12 & -35.11 \\
\hline$\delta{ }^{13} C_{\mathrm{PDB}}(\%)$ & -1.29 & -1.05 & -3.83 & -4.25 & 0.15 & -2.22 & -3.73 & -1.05 & -2.53 & -5.35 & -7.67 & -1.82 & -0.86 & -13.42 \\
\hline $\mathrm{F}(\mathrm{mg} / \mathrm{L})$ & 0.00 & 1.22 & 1.99 & 0.60 & 0.99 & 0.88 & 1.47 & 1.39 & 1.30 & 1.00 & 0.29 & 0.93 & 0.00 & 0.00 \\
\hline 1 (mg/L) & 16,666 & 21,439 & 3,392 & 14 & 25,088 & 20,786 & 8,742 & 25,828 & 14,637 & 15,333 & 435 & 1,294 & 40,033 & 36,602 \\
\hline $\mathrm{Br}(\mathrm{mg} / \mathrm{L})$ & 37.99 & 51.48 & 7.17 & 0.02 & 39.69 & 32.64 & 13.15 & 42.19 & 24.13 & 34.12 & 0.62 & 2.04 & 72.95 & 83.21 \\
\hline $\mathrm{SO}_{4}(\mathrm{mg} / \mathrm{L})$ & 6.54 & 0.70 & 1.12 & 59.02 & 2.41 & 2.41 & 24.92 & 2.77 & 10.30 & 1.69 & 15.27 & 23.06 & 10.25 & 2.43 \\
\hline $\mathrm{Li}(\mathrm{mg} / \mathrm{L})$ & 38.16 & 40.75 & 6.50 & 0.03 & 35.78 & 30.76 & 14.42 & 36.69 & 22.97 & 20.86 & 0.05 & 2.08 & 51.90 & 33.81 \\
\hline $\mathrm{Na}(\mathrm{mg} / \mathrm{L})$ & 9,623 & 12,618 & 1,743 & 18 & 11,945 & 10,127 & 4,700 & 12,189 & 7,805 & 9,014 & 23 & 704 & 20,077 & 18,379 \\
\hline $\mathrm{NH}_{4}(\mathrm{mg} / \mathrm{L})$ & 7.77 & 5.46 & 0.86 & 0.03 & 4.82 & 4.42 & 2.33 & 5.23 & 2.52 & 4.17 & 0.00 & 0.04 & 8.22 & 3.06 \\
\hline $\mathrm{K}(\mathrm{mg} / \mathrm{L})$ & 959 & 1,372 & 208 & 3 & 2,525 & 2,153 & 1,000 & 2,593 & 1,388 & 332 & 4 & 131 & 1,930 & 112 \\
\hline $\mathrm{Mg}(\mathrm{mg} / \mathrm{L})$ & 284 & 114 & 35 & 1 & 15 & 12 & 15 & 17 & 29 & 144 & 0 & 4 & 136 & 511 \\
\hline $\mathrm{Ca}(\mathrm{mg} / \mathrm{L})$ & 629 & 985 & 491 & 23 & 2,192 & 1,845 & 627 & 2,356 & 1,283 & 860 & 8 & 108 & 3,006 & 2,598 \\
\hline $\mathrm{HCO}_{3}(\mathrm{mg} / \mathrm{L})$ & 3,803 & 3,154 & 781 & 30 & 26 & 203 & 473 & 137 & 435 & 1,623 & 93 & 150 & 1,293 & 214 \\
\hline${ }^{3} \mathrm{He} /{ }^{4} \mathrm{He}\left(10^{-6}\right)$ & $\begin{array}{l}7.11 \\
{[8.92]}\end{array}$ & 5.46 & $\begin{array}{l}8.98 \\
{[9.42]}\end{array}$ & 10.29 & 3.26 & 3.34 & $\begin{array}{l}3.84 \\
{[10.51]}\end{array}$ & na & 6.73 & 5.07 & 7.62 & na & 6.69 & na \\
\hline${ }^{3} \mathrm{He} /{ }^{4} \mathrm{He}(\mathrm{Ra})$ & $\begin{array}{l}5.08 \\
{[6.37]}\end{array}$ & 3.90 & $\begin{array}{l}6.41 \\
{[6.73]}\end{array}$ & 7.35 & 2.33 & 2.38 & $\begin{array}{l}2.75 \\
{[7.51]}\end{array}$ & na & 4.80 & 3.62 & 5.44 & na & 4.78 & na \\
\hline${ }^{4} \mathrm{He}\left(10^{-8}\right)$ & $13.87[11.51]$ & 3.90 & $\begin{array}{l}499.7 \\
{[646.9]}\end{array}$ & 191.10 & 1.77 & 2.52 & $\begin{array}{l}4.08 \\
{[3.35]}\end{array}$ & na & 8.29 & 17.83 & 88.18 & na & 413.90 & na \\
\hline${ }^{20} \mathrm{Ne}\left(10^{-7}\right)$ & $\begin{array}{l}0.79 \\
{[0.58]}\end{array}$ & 0.43 & $\begin{array}{l}0.44 \\
{[2.83]}\end{array}$ & 0.18 & 0.42 & 0.67 & $\begin{array}{l}0.98 \\
{[0.042]}\end{array}$ & na & 0.89 & 1.63 & 9.17 & na & na & na \\
\hline${ }^{4} \mathrm{He} /{ }^{20} \mathrm{Ne}$ & $\begin{array}{l}1.75 \\
{[19.90]}\end{array}$ & 0.91 & $\begin{array}{l}113.9 \\
{[228.3]}\end{array}$ & 106.15 & 0.43 & 0.38 & $\begin{array}{l}0.42 \\
{[79.5]}\end{array}$ & na & 0.93 & 1.10 & 0.96 & na & na & na \\
\hline $\mathrm{Sr}(\mathrm{mg} / \mathrm{L})$ & 20.23 & 43.34 & 8.28 & 0.12 & 43.39 & 37.08 & 11.09 & 41.01 & 28.88 & 48.32 & 0.76 & 0.77 & 80.35 & 93.94 \\
\hline${ }^{87} \mathrm{Sr} /{ }^{86} \mathrm{Sr}$ & 0.70926 & 0.70878 & 0.70854 & 0.70846 & 0.70853 & na & na & na & na & 0.70879 & 0.70866 & na & na & 0.70866 \\
\hline
\end{tabular}

nk, not known; na, not analyzed. The concentrations of noble gases are shown in [ $\mathrm{cm}^{3}$ STP (noble gas)/g (sampled water)]. TG-1, AG-1, and AG-5 are the gas samples for which the $\mathrm{He}$ and $\mathrm{Ne}$ data shown in square brackets are available.

such as $\mathrm{Cl}, \mathrm{Na}, \mathrm{Li}, \mathrm{Br}, \mathrm{Ca}, \mathrm{Sr}, \mathrm{NH}_{4}$, and $\mathrm{K}$ have sharp positive correlations with $\delta^{18} \mathrm{O}$ and $\delta \mathrm{D}$, resulting in a strong correlation with the electrical conductivity (EC indicated by asterisk in Figure 2). On the contrary, ${ }^{3} \mathrm{He} /{ }^{4} \mathrm{He}$ and $\mathrm{SO}_{4}$ are broadly and negatively correlated with $\delta^{18} \mathrm{O}, \delta \mathrm{D}$, and other solute elements, whereas ${ }^{87} \mathrm{Sr} /{ }^{86} \mathrm{Sr}, \delta^{13} \mathrm{C}, \mathrm{HCO}_{3}$, and $\mathrm{F}$, as well as temperature and $\mathrm{pH}$, are poorly correlated with the major solute elements. The sharp positive correlation among $\delta^{18} \mathrm{O}, \delta \mathrm{D}$, and the major solute elements is detailed below.

Figure 3 presents the $\delta^{18} \mathrm{O}-\delta \mathrm{D}$ diagram, in which the data form a linear trend toward a magmatic water composition distinct from the meteoric water line or seawater. Figure 4 presents the selected major element and $\delta \mathrm{D}$ diagrams, again showing linear trends of least squares regression with high coefficients of determination $\left(R^{2}=0.84\right.$ to 0.99 ). In Figure 3 and in the bottom two subpanels of Figure 4, each data point is labeled with the (abbreviated) sample number as in Tables 1 and 2, indicating a consistent sample array from AW-2, which is closer to or almost on the meteoric water line, to AW-11, which is closer to magmatic water. It should be noted that the same symbols are used in Figures 2 and 3; light blue diamonds represent the samples from Arima, and dark blue diamonds represent the samples from Takarazuka.

The new dataset and the linear trends confirm the previous results, which suggest mixing of local meteoric water in the Arima area $(\delta \mathrm{D}$ approximately $-50 \%$ with nearly 
zero for all the solute concentrations, Masuda et al. 1985) and a deep-seated brine (e.g., Matsubaya et al. 1973; Tanaka et al. 1984; Masuda et al. 1985). Based on the new data, we quantitatively estimated the deep brine composition. The previously observed relationship between ${ }^{3} \mathrm{H}$ and $\delta \mathrm{D}$ of the Arima hot spring waters, $\delta \mathrm{D}$ of the tritiumfree water, i.e., a pure deep brine, is inferred to be $-30 \%$ to $-35 \%$ o (Tanaka et al. 1984). Then, the least squares regression lines at $\delta \mathrm{D}=-30 \%$ to $-35 \%$ provide the estimate on the brine composition: $\mathrm{Cl}^{-}=42,000 \mathrm{mg} / \mathrm{L}$, $\mathrm{Na}^{+}=21,000 \mathrm{mg} / \mathrm{L}, \quad \mathrm{Li}^{+}=55 \mathrm{mg} / \mathrm{L}, \quad \mathrm{Br}^{-}=84 \mathrm{mg} / \mathrm{L}$, $\mathrm{Ca}^{2+}=3,100 \mathrm{mg} / \mathrm{L}, \mathrm{Sr}^{2+}=86 \mathrm{mg} / \mathrm{L}, \mathrm{NH}_{4}^{+}=8.8 \mathrm{mg} / \mathrm{L}$, $\mathrm{K}^{+}=3,700 \mathrm{mg} / \mathrm{L}$, and $\delta^{18} \mathrm{O}=+6 \%$ at $\delta \mathrm{D}=-33 \%$, which are similar to but slightly more diluted than the previous estimates by Masuda et al. (1985).

\section{Oxygen and hydrogen isotopes of slab-derived fluid}

In order to test the origin of the deep brine, a numerical model was developed to estimate the oxygen and hydrogen isotope compositions of the slab-derived fluid. The model considers the thermal structure along the subducting slab in a 2D across-arc section, stability and dehydration reaction of hydrous mineral phases, and the resultant partitioning of oxygen and hydrogen isotopes between the fluid and the residual mineral phases.

First, the thermal structure of the subduction zone was calculated because dehydration from subducting slabs is controlled thermodynamically and hence chiefly by temperature and pressure. Since dehydration mainly occurs within hydrated oceanic crusts consisting of both sediment and AOC rather than the underlying oceanic mantle (e.g., Iwamori 2007), the temperature distribution along the surface of a slab is calculated as a function of subduction velocity $(V)$, slab age $(a)$, and subduction angle $(\theta)$, using an analytical expression based on that reported by England and Wilkins (2004). As a result, we estimated the thermal profile along the slab surface for the subducting Philippine Sea slab $\left(V=4 \mathrm{~cm} /\right.$ year, $\left.a=15 \mathrm{Ma}, \theta=20^{\circ}\right)$ beneath the southwestern Japan arc, as well as that for the Pacific slab $\left(V=10 \mathrm{~cm} /\right.$ year, $\left.a=120 \mathrm{Ma}, \theta=30^{\circ}\right)$ beneath the northeastern Japan arc. These thermal profiles, shown in Additional file 1: Figure S1, are similar to those obtained in 2D numerical simulation (e.g., approximately $600^{\circ} \mathrm{C}$ at $3 \mathrm{GPa}$; Iwamori 2007).

Next, slab dehydration and the isotopic fractionation of oxygen and hydrogen were calculated, based on the phase relation of the subducted materials. Although oceanic sediments initially contain 10 to $30 \mathrm{wt} \% \mathrm{H}_{2} \mathrm{O}$ (Plank and Langmuir 1998), most of water is liberated, decreasing to 2 to $4 \mathrm{wt} \%$ by extensive compaction and dehydration of minerals at depths shallower than $30 \mathrm{~km}$ (You et al. 1996; Hyndman and Peacock 2003; Kasahara 2003). The sedimentary column currently delivered to deep sea trenches is typically 50 to $500-\mathrm{m}$ thick, and sediment 350-m-thick subducts from the Nankai Trough (Plank and Langmuir 1998). These values are $1 / 100$ to 


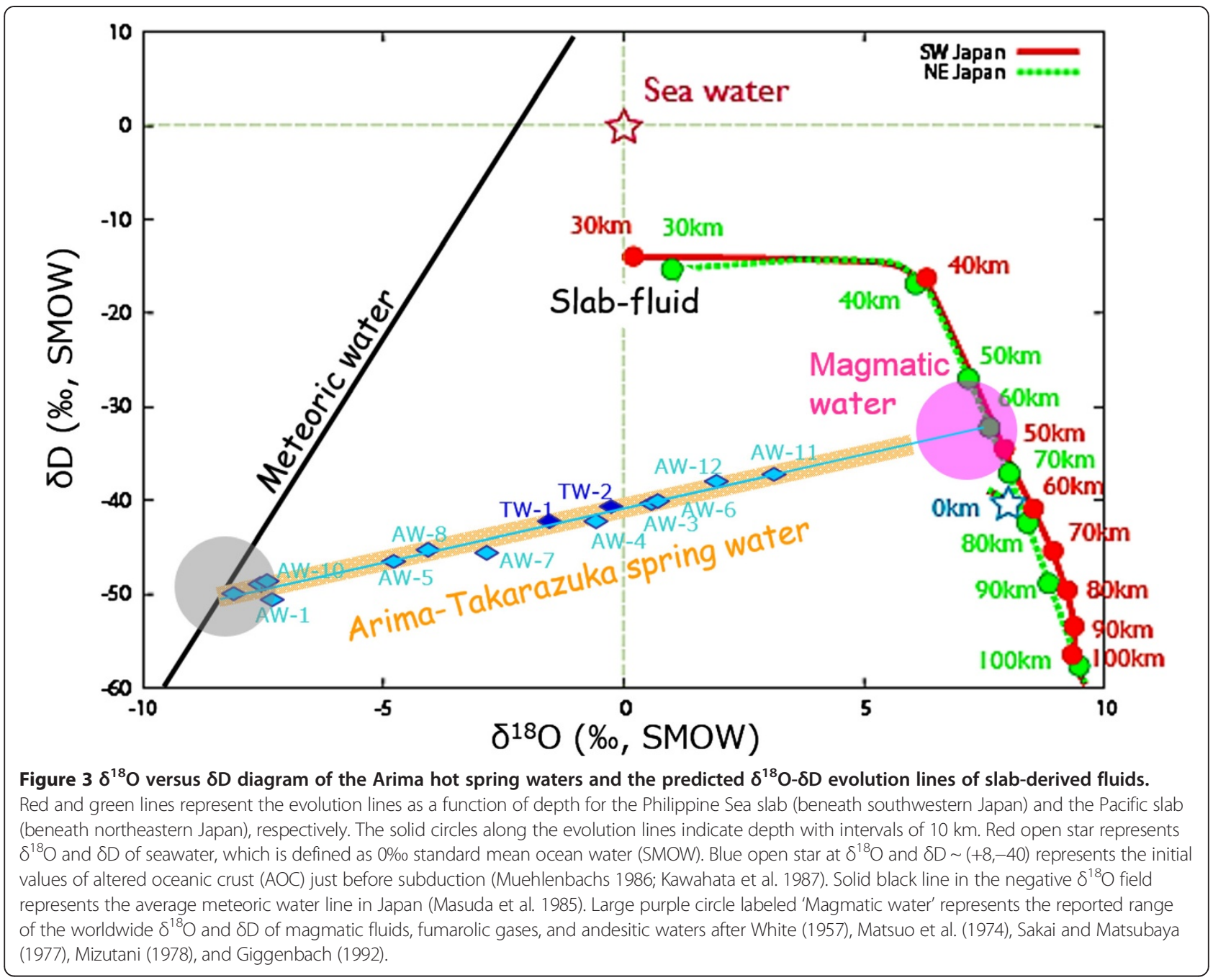

$1 / 10$ thinner than the AOC thickness, limiting its impact on the water budget in subduction zones. Considering these factors, although oceanic sediments still contain 1 to $2 \mathrm{wt} \%$ of $\mathrm{H}_{2} \mathrm{O}$ at depths greater than $100 \mathrm{~km}$, the AOC-derived fluids are thought to be a major source that supplies deep-seated fluids to the overlying mantle wedge and the arc crust over the slab depth ranging from 30 to $100 \mathrm{~km}$ (Iwamori 2007), including the Arima area (Figure 1). Therefore, to simplify the model, we considered only dehydration of AOC and its phase relations for dehydration reaction (Schmidt and Poli 1998). It should be noted, however, that several key elements/isotopes such as carbon and lead, which are particularly concentrated in sediments, may have significant impacts on the fluid compositions (e.g., Sano and Marty 1995; Aizawa et al. 1999; Nakamura et al. 2008), as will be subsequently discussed.

A model was then designed to estimate the isotopic characteristics of slab-derived fluids for the hydrogen and oxygen stable isotopic ratios that constitute the characteristic features of Arima-type brine. The major constituent minerals of AOC at the pressure-temperature condition beneath the Arima area (i.e., 1.5 to $2.4 \mathrm{GPa}$ and $400^{\circ} \mathrm{C}$ to $500^{\circ} \mathrm{C}$, including uncertainty in the estimates), where major dehydration of AOC occurs, are amphibole (22\% to $48 \%$ in modal composition), lawsonite (22\% to $36 \%$ ), chlorite ( $0 \%$ to $13 \%$ ), and epidote ( $9 \%$ to $22 \%$; Schmidt and Poli 1998). Accordingly, the following water/mineral isotopic fractionation factors $(\alpha)$ for the major constituent minerals of AOC are used.

Amphibole: The hydrogen isotopic fractionation factor (Graham et al. 1984) is expressed with

$$
\begin{aligned}
10^{3} \ln \alpha & =+23\left(T<750^{\circ} \mathrm{C}\right), \text { or } \\
& =26\left(10^{6} T^{-2}\right)-3\left(T>750^{\circ} \mathrm{C}\right)
\end{aligned}
$$

and the oxygen isotopic fractionation factor (Zheng et al. 1994) follows 



Figure 4 Variation diagrams for chlorine versus major elements and $\delta D$ for Arima hot spring waters. The least squares fitting line expressed by the equation in each subpanel is shown with the coefficient of determination $\left(R^{2}\right)$.

$$
10^{3} \ln \alpha=-0.42\left(10^{6} T^{-2}\right)+2.4
$$

Lawsonite: The hydrogen isotopic fractionation factor (Suzuoki and Epstein 1976) is expressed with

$$
\begin{aligned}
10^{3} \ln \alpha & =+26.4\left(T<350^{\circ} \mathrm{C}\right), \text { or } \\
& =22.4\left(10^{6} T^{-2}\right)-28.2-2\left(10^{3} T^{-1}\right)\left(T>350^{\circ} \mathrm{C}\right)
\end{aligned}
$$

and the oxygen isotopic fractionation factor (Wenner and Taylor 1971) follows

$$
10^{3} \ln \alpha=-2.3\left(10^{6} T^{-2}\right)+3.8
$$

Chlorite: The hydrogen isotopic fractionation factor (O'Neil 1986) is expressed with

$$
\begin{aligned}
10^{3} \ln \alpha & =+32.7\left(T<350^{\circ} \mathrm{C}\right), \text { or } \\
& =2.67\left(10^{6} T^{-2}\right)+25.3\left(T>350^{\circ} \mathrm{C}\right)
\end{aligned}
$$

and the oxygen isotopic fractionation factor (Wenner and Taylor 1971) follows

$$
10^{3} \ln \alpha=-1.56\left(10^{6} T^{-2}\right)+4.70
$$

where $T$ is the absolute temperature. Epidote is one of the major constituent minerals in AOC at up to $22 \mathrm{wt} \%$ (Schmidt and Poli 1998) for the $P-T$ range of interest up to $3 \mathrm{GPa}$ and $600^{\circ} \mathrm{C}$ in this study, respectively. Matthews et al. (1983) reported that below $600^{\circ} \mathrm{C}$, the oxygen exchange reaction is very slow between water and zoisite, the Fe-free end-member of epidote group minerals; therefore, no isotopic fractionation occurs. Instead, dissolution-precipitation appears to occur. In addition, the zoisite-water fractionation factor constrained by mineral-pair equations is around unity (Matthews et al. 1983), causing no ${ }^{18} \mathrm{O} /{ }^{16} \mathrm{O}$ fractionation. For these reasons, we ignored epidote in our estimates.

The Rayleigh fractionation of oxygen and hydrogen isotopes was calculated by numerically integrating the following equation along the calculated $P-T$ path for the Philippine Sea slab to obtain the compositional path in Figure 3: $\Delta \delta_{\mathrm{f}} \quad / 1,000=-(1-F) / F \quad\left(\alpha_{\mathrm{f} / \mathrm{r}}-1\right) \times \ln (1-F)$ (Equation 7), where $\Delta \delta_{\mathrm{f}}$ is the change in isotopic ratio of the fluid corresponding to the infinitesimal change in $P$ $T$ (\%), $F$ is the extent of dehydration reaction constrained from the phase diagram as a function of $P-T$ (weight fraction), and $\alpha_{\mathrm{f} / \mathrm{r}}$ is the isotopic fractionation coefficient between the fluid and the bulk rock 



Figure 5 Helium and carbon systematics of the sampled waters and gases. (a) ${ }^{4} \mathrm{He} /{ }^{20} \mathrm{He}$ versus ${ }^{3} \mathrm{He} /{ }^{4} \mathrm{Ne}$ diagram of the sampled waters and gases. Light blue diamonds represent samples from Arima; dark blue diamonds (TW-1 and TW-2) represent samples from Takarazuka. Red circles represent gas samples. Two mixing curves are drawn, one between air-saturated water (ASW) and the upper mantle component and the other between ASW and a component having ${ }^{3} \mathrm{He} /{ }^{4} \mathrm{He}$ ratio of $8 \times 10^{-6}$, considering possible but slight crustal contamination. (b) $\delta^{13} \mathrm{C}$ versus $\mathrm{CO}_{2} /^{3} \mathrm{He}$ diagram of the sampled waters. Yellow, pink, and purple boxes represent the three end-members of sediment-, limestone-, and mid-ocean ridge basalt (MORB)-derived carbon, respectively (Sano and Marty 1995). Solid curves represent mixing between MORB and limestone and MORB and sediment. Open gray box represents the compositional range for arc volcanic gases (Sano and Marty 1995).

calculated as $\Sigma X_{\mathrm{i}} \alpha_{\mathrm{i}}$, where $\mathrm{X}_{\mathrm{i}}$ represents the weight fraction of mineral $i$, and $\alpha_{\mathrm{i}}$ is the fractionation factor derived from Equation 1 to 6 .

The calculation starts with an average composition of AOC $\left(\delta \mathrm{D}=-40 \%\right.$ o, $\delta^{18} \mathrm{O}=+8 \%$ o $)$ obtained from a DSDP Hole 504B drill core $>1,000-\mathrm{m}$ long that includes finegrained basalt to dolerite (Muehlenbachs 1986; Kawahata et al. 1987), as shown by the open star labeled ' $0 \mathrm{~km}$ ' in Figure 3. The $\delta \mathrm{D}$ value used (i.e., $-40 \%$ ) is within the range reported from ODP/IODP Hole 1256D ( $-64 \%$ to $-25 \%$, Shilobreeva et al. 2011). A shallow dehydration of this AOC produces relatively light oxygen isotopes $\left(\delta^{18} \mathrm{O}\right.$ of approximately $0 \%$ ) and heavy hydrogen isotopes ( $\delta \mathrm{D}$ of approximately $-15 \%$ ) compared with those estimated in the Arima deep brine, which evolves toward the bottom right of the diagram. The results, showing larger $\delta^{18} \mathrm{O}$ and smaller $\delta \mathrm{D}$ values as the subduction progresses, reflect continuous dehydration and Rayleigh isotopic fractionation. The subducted young Shikoku Basin and its extinct spreading center (approximately 15 Ma; Okino et al. 1994; Sano et al. 2009) beneath the Arima area may share thermal and 




Figure 6 Analyzed Sr concentration expressed by $1 / \mathrm{Sr}\left(\mathrm{ppm}^{-1}\right)$ versus ${ }^{87} \mathrm{Sr} /{ }^{86} \mathrm{Sr}$ of the Arima-type brine. Sr concentration expressed by $1 / \mathrm{Sr}\left(\mathrm{ppm}^{-1}\right)$ versus ${ }^{87} \mathrm{Sr} /{ }^{86} \mathrm{Sr}$ of the Arima-type brine analyzed in this study, together with the data of the Rokko granitoids and the Arima group consisting mainly of rhyolitic welded tuffs (Terakado and Nohda 1993). Large red and green stars represent slab fluid compositions derived from the subducted Philippine Sea Plate and Pacific Plate, respectively (Nakamura and Iwamori 2009). The analytical errors of ${ }^{87} \mathrm{Sr} /{ }^{86} \mathrm{Sr}$ ratio in this study are approximately $3 \times 10^{-6}$.

hydration conditions with a young oceanic crust at the 504B site off the Costa Rica Rift (approximately $6 \mathrm{Ma}$ ), partly justifying the assumed isotopic composition in Figure 3. Nevertheless, subducting slabs exhibit significant compositional variability, e.g., $\delta \mathrm{D}=-30 \%$ to $-60 \%$, including sediment, $\mathrm{AOC}$, and serpentinite (Kawahata et al. 1987; Giggenbach 1992; Matsuhisa 1992; Shaw et al. 2008), and causes significant uncertainty in the quantitative results of our model. As a consequence, the slab dehydration depth estimated for the Arima deep brine ranges from 45 to $70 \mathrm{~km}$, as shown by the pink circle in Figure 3).

Beneath the Arima area, the depth of the Philippine Sea slab surface is estimated to be 50 to $70 \mathrm{~km}$ with relatively large uncertainty (Figure 1; Nakajima and Hasegawa 2007; Hirose et al. 2008). Our numerical model suggests that the slab-derived fluid at such depth has an isotopic composition similar to that of geochemically estimated deep brine within the uncertainty, as shown in Figure 3.

The estimated brine composition of $\delta \mathrm{D}$ at approximately $-30 \%$ is similar to that estimated from analysis on back-arc basin basalts or melt inclusions from the Mariana subduction zone such as $-25 \%$ (Poreda 1985) and $-32 \%$ (Shaw et al. 2008), respectively, and the mass balance of subduction zone-scale material cycling at $\delta \mathrm{D}=-27 \%$ o (Kazahaya 1997). The compositional range resembles magmatic fluids, although Arima is far from the volcanoes and is located in the forearc region in terms of northwestward subduction of the Philippine Sea Plate from the Nankai Trough. Westward subduction of the Pacific Plate causes magmatism in central Japan (e.g., Nakamura et al. 2008); Arima is located approximately $300 \mathrm{~km}$ west in the backarc region of the magmatism (Figure 1). The current understanding of the magma genesis, including the regional understanding along the entire Japan arcs (Iwamori 2007), indicates no magmatic production or supply beneath the Arima area.

\section{Discussion and conclusions}

The ${ }^{3} \mathrm{He} /{ }^{4} \mathrm{He}$ ratio may provide crucial information of whether the observed geochemical features reflect the slab-derived fluid directly or if they are affected significantly by arc crust during ascent because the incorporation of crustal components significantly reduces the ratio. Figure 5a shows the ${ }^{3} \mathrm{He} /{ }^{4} \mathrm{He}$ ratios for the brine samples as well as the gas samples from the three gasrich brines. Almost all of the sample plots within the two mixing curves including one between air-saturated water (ASW) and the upper mantle component (8 Ra) and the other between ASW and a component having ${ }^{3} \mathrm{He} /{ }^{4} \mathrm{He}$ ratios of $8 \times 10^{-6}$ (5.7 Ra), indicating high contribution of the mantle component with minor crustal contamination (Figure 5a). Masuda et al. (1985) argued that the high ${ }^{3} \mathrm{He} /{ }^{4} \mathrm{He}$ ratios of the Arima hot spring brines are attributed to deep-lying magma and its interaction with the crustal rocks, together with diluted 
carbonated waters from the basement Paleozoic sedimentary rocks and the Cretaceous to Paleogene acidic igneous rocks that account for the overall $\delta^{18} \mathrm{O}-\delta \mathrm{D}$ and solute variations of the Arima hot spring waters. Magmatic activity is certainly important for the origin of deep brines in some geothermal fields such as Salton Sea and Cerro Prieto with high $\mathrm{Cl}$ content and high ${ }^{3} \mathrm{He} /{ }^{4} \mathrm{He}$ ratios, where heat and material input (particularly gas in this case) from subaerial but mid-ocean ridge basalt (MORB)-type magmatism at depth interacts with the overlying thick sedimentary basin (Mazzini et al. 2011; Schmitt et al. 2013).

However, as discussed in the previous section, the Arima hot spring is different in that no magmatic activity is expected beneath the area and no thick sedimentary basin exists (Kozuki 1962). Since the absolute concentrations of ${ }^{3} \mathrm{He}$ in $\mathrm{AOC}$, oceanic sediment, and ASW are four to six orders of magnitude lower than those in MORB (Zelenski et al. 2012), the high ${ }^{3} \mathrm{He} /{ }^{4} \mathrm{He}$ ratios found in the Arima hot springs are attributed to mantle helium incorporated in the fluid upon its ascent in the mantle. Arima is located in an area with hot springs of relatively high ${ }^{3} \mathrm{He} /{ }^{4} \mathrm{He}$ ratios (greater than $2.5 \mathrm{Ra}$ ) known as the Kinki Spot (Sano and Wakita 1985; Figure 1). The Philippine Sea slab subducted beneath the Kinki Spot is young and hot because it is associated with the former spreading ridge (Sano et al. 2009), which may have enhanced the degassing of the mantle.

The ${ }^{3} \mathrm{He} /{ }^{4} \mathrm{He}$ ratios are along the mixing line between the air and the mantle component, although the proportions of mixing differ from those identified from the solute concentrations (Figure 4). It is argued that shallow reservoirs exist beneath Arima (e.g., Masuda et al. 1985), where the meteoric water saturated with air mixes with both the deep brine and the exsolved gas and may cause variable mixing of the solutes and the gases. The broad negative correlation between the major solute elements and ${ }^{3} \mathrm{He} /{ }^{4} \mathrm{He}$ (Figure 2; Figure 5a) suggests that the spring waters diluted significantly by meteoric water in the shallow reservoir (e.g., AW-1, AW-2, and AW-9, Figures 2 and 3) have been fluxed by high ${ }^{3} \mathrm{He} /{ }^{4} \mathrm{He}$ gases (e.g., AG-1 and AG-5, Table 2 and Figure 5a) possibly derived from the deep brine (e.g., AW-3, AW-4, and AW-5) that ascends to the surface without being regassed.

Carbon dioxide is one of the dominant volatiles in magmatic fluids and gases in subduction zones, which is also one of the distinguishing characteristics of Arimatype brine, and could have originated from slab fluids (Jarrard 2003; Fischer 2008). The plausible sources of carbon are (1) organic carbon in sediments, which are mainly in the continental crust although subducted oceanic sediments are reported to have similar values, (2) carbonate in subducted MORB (AOC), and (3) inorganic carbonate in subducted marine limestones
(Nissenbaum et al. 1972; Marty and Jambon 1987; Sano and Marty 1995). In order to identify the origin of carbon, the correlation between $\delta^{13} \mathrm{C}$ and $\mathrm{CO}_{2} /{ }^{3} \mathrm{He}$ ratios is useful; in fact, hot spring gases in subduction zones can be explained by three-component mixing, as shown in Figure 5b (Sano and Marty 1995). Within this context, the observed carbon isotopic compositions of the Arima hot spring waters also suggest possible involvement of deep-seated slab materials such as subducted MORB and limestone rather than organic carbon from a shallow sedimentary reservoir (Figure 5b). The poor correlation between the major solute, mostly derived from subducted MORB, and the carbon isotopic ratios, mostly buffered by subducted limestone, may reflect decoupled processes of different lithologies in a subducted slab such as dehydration versus decarbonation.

The $\mathrm{CO}_{2} /{ }^{3} \mathrm{He}$ ratios vary significantly over four orders of magnitude with broadly constant $\delta^{13} \mathrm{C}$ (Figure 5b). Low $\mathrm{CO}_{2} /{ }^{3} \mathrm{He}$ samples (AW-1, AW-2, and AW-9; Figure 5b) exhibited relatively high ${ }^{3} \mathrm{He} /{ }^{4} \mathrm{He}$ (Figure 5a) and low solute concentrations (Figure 4), when compared with the high $\mathrm{CO}_{2} /{ }^{3} \mathrm{He}$ samples (AW-3, AW-4, and AW-5) with low ${ }^{3} \mathrm{He} /{ }^{4} \mathrm{He}$ and high solute concentrations. Sano and Marty (1995) argued that the $\mathrm{CO}_{2} /$ ${ }^{3} \mathrm{He}$ ratio of bubbling gas is lower than that of volcanic hydrothermal water which exsolves the gas because $\mathrm{CO}_{2}$ is much more soluble to water than He. They suggested that significant $\mathrm{CO}_{2} /{ }^{3} \mathrm{He}$ fractionation occurs during the ascent of deep hydrothermal fluids associated with decompressional degassing. Such a fractionation mechanism may consistently explain the lower $\mathrm{CO}_{2} /{ }^{3} \mathrm{He}$ samples (AW-1, AW-2, AW-9) that have been fluxed by the gas with low $\mathrm{CO}_{2} /{ }^{3} \mathrm{He}$ and high ${ }^{3} \mathrm{He} /{ }^{4} \mathrm{He}$ ratios in a meteoric water-dominated shallow reservoir, in addition to the high $\mathrm{CO}_{2} /{ }^{3} \mathrm{He}$ samples (AW-3, AW-4, AW-5) that contain more of the deep brine component from which the gas has been exsolved.

It has been argued that a high concentration of $\mathrm{Cl}^{-}$indicates an extensive water-rock interaction either at depth of a high temperature or with the granitic basement rocks at a relatively shallow depth (Edmunds et al. 1985). In the latter case, $\mathrm{Cl}^{-}$is derived from granitic rocks by acid hydrolysis of biotite and plagioclase. Since hydrolysis of biotite could generate $\mathrm{Cl}^{-}, \mathrm{Li}^{+}, \mathrm{K}^{+}$, and other species in the groundwater, $\mathrm{Cl}^{-}$and $\mathrm{Li}^{+}$can be considered as conservative products of biotite alteration. On the contrary, the acid hydrolysis of plagioclase may contribute to the principal sources of $\mathrm{Na}^{+}$and $\mathrm{Ca}^{2+}$ in the groundwater without supplying $\mathrm{Cl}^{-}$or $\mathrm{Li}^{+}$. Molar $\mathrm{Cl}^{-} / \mathrm{Li}^{+}$and $\mathrm{Na}^{+} / \mathrm{Ca}^{2+}$ ratios of the sampled waters, however, reach up to about 150 and 12, respectively, which are significantly larger than the stoichiometry deduced from the above reactions. Although the possibility of such an excess of $\mathrm{Na}^{+}$and $\mathrm{Cl}^{-}$owing to decreases in $\mathrm{Ca}^{2+}, \mathrm{K}^{+}$, 
and $\mathrm{Mg}^{2+}$ through the formation of clay minerals in the aquifer cannot be entirely ruled out, it appears difficult to attain the high salinity (approximately 42,000 ppm Cl) solely by chemical interactions between the basement granites and water (Edmunds et al. 1985).

The concentrations and isotopic ratios of $\mathrm{Sr}$ support binary mixing between diluted near-surface water (approximately represented by sample AW-2) and highSr deep brine (represented by AW-12; Figure 6). The estimated ${ }^{87} \mathrm{Sr} /{ }^{86} \mathrm{Sr}$ ratio of the deep brine is close to the estimated ratio of the Philippine Sea slab-derived fluid at 0.71087 and is distinct from the Pacific slabderived fluid at 0.70538 , possibly because the former has more terrigenous components subducted from the Nankai Trough (Plank and Langmuir 1998; Nakamura et al. 2008). The brine composition is also close to the lowermost range of the basement rocks including Rokko granite and the Arima group (approximately 0.707 to 0.710; Terakado and Nohda 1993). The interactions between the solutions and the basement rocks may have, to some extent, perturbed the ${ }^{87} \mathrm{Sr} /{ }^{86} \mathrm{Sr}$ ratios of the brine, which could have caused the poor correlation between the major solute concentrations (including $\mathrm{Sr}$ ) and ${ }^{87} \mathrm{Sr} /{ }^{86} \mathrm{Sr}$. However, the arguments above in terms of helium, carbon, and major solute stoichiometry suggest that the one end-member of the trend is likely to be deep brine originating from the subducted Philippine Sea slab, rather than the host country rocks.

Numerical forward modeling in this study suggests that slab fluids with $\delta^{18} \mathrm{O}-\delta \mathrm{D}$ values similar to the Arima-type brine are produced along the subducted Pacific slab beneath the northeastern Japan arc (Figure 3). However, the produced fluid reacts with the mantle wedge just above the slab to form serpentinite due to the cold geotherm along the slab (Iwamori 2007). Therefore, the fluid is absorbed by the mantle and subducted to the deeper part along the slab, which may explain the absence of the Arima-type brine, to our knowledge, in the non-volcanic forearc region of northeastern Japan arc. On the contrary, in a warmer environment beneath the southwestern Japan arc, such an 'absorption' effect by serpentinite is greatly reduced (Iwamori 2007), and the slab fluid may escape to the surface without significant reaction with the country rocks, possibly guided by large faults at crustal levels.

It is also noted that the amount of fluid generated from the slab is maximum at depths of 30 to $80 \mathrm{~km}$ and is greatly reduced deeper than $100 \mathrm{~km}$ in most subduction zones (Iwamori 1998). Instead, beneath the northeastern Japan arc, the subducted serpentinite along the slab undergoes dehydration and supplies fluids upward beneath the arc volcanic zones, causing melting in a hightemperature region of the central part of the mantle wedge
(Iwamori 1998). Then, hydrous magma is fed to a shallow chamber, where degassing may create volcanic waters and gases. Therefore, $\delta^{18} \mathrm{O}-\delta \mathrm{D}$ compositions of the volcanic thermal waters, widely known as 'andesitic water' having $\delta^{18} \mathrm{O}=+5 \%$ o to $+10 \%$ and $\delta \mathrm{D}=-10 \%$ o to $-30 \%$ (Taran et al. 1989; Giggenbach 1992), integrate and reflect these processes of slab dehydration, sepentinite formationdehydration, reaction with the mantle to cause melting, and degassing, as discussed by Matsuhisa (1992). In this context, andesitic water and the Arima-type brine as suggested in this study are believed to reflect different origins, although their $\delta^{18} \mathrm{O}-\delta \mathrm{D}$ ranges overlap.

The estimated solute concentrations in the Arima deep brine (e.g., 42,000 ppm Cl; 3,700 ppm K; 84 ppm $\mathrm{Br} ; \mathrm{Br} / \mathrm{Cl} \sim 2.0 \times 10^{-3}$ ) are consistent with the recent knowledge on slab-derived fluids, e.g., 12,000 to $240,000 \mathrm{ppm} \mathrm{Cl}, 600$ to $3,700 \mathrm{ppm}$ for $\mathrm{K}, \mathrm{Br} / \mathrm{Cl} \sim 1.0$ to $3.7 \times 10^{-3}$ for fluids derived from subducted serpentinite (Kendrick et al. 2011), and $5.1 \mathrm{wt} \% \mathrm{NaCl}$ (approximately $30,000 \mathrm{ppm} \mathrm{Cl}$ ) for fluid inclusions in the mantle xenoliths (Kawamoto et al. 2013). On the contrary, the Philippine Sea slab-derived fluid compositions estimated from volcanic rocks in central Japan (Nakamura and Iwamori 2013) have higher concentrations for $\mathrm{K}$ and $\mathrm{Sr}$ (64,000 and $268 \mathrm{ppm}$, respectively), possibly reflecting different dehydration conditions of higher pressure and temperature beneath the volcanic region compared with those in the forearc region in southwestern Japan (Nakamura et al. 2014). It is also noted that during deep processes of dehydration and melting in subduction zones, $\mathrm{Cl}$ and $\mathrm{F}$ are reported to behave very differently (Straub and Layne 2003), which may explain the poor correlation between the major solute including $\mathrm{Cl}$ and $\mathrm{F}$ (Figure 2).

In any case, the composition of the Arima brine appears to retain the deep fluid signatures derived from multiple sources such as the subducted Philippine Sea slab and the overlying mantle, including (i) AOC for most water and hence hydrogen and oxygen isotopes in addition to associated elements such as $\mathrm{Cl}, \mathrm{Na}, \mathrm{Li}, \mathrm{Br}$, $\mathrm{Ca}$, and $\mathrm{Sr}$ (Figure 2), (ii) subducted sediment, particularly limestone, for carbon, and (iii) mantle wedge for a high ${ }^{3} \mathrm{He} /{ }^{4} \mathrm{He}$ component. These signatures indicate that deep-seated fluid may reach the surface without significant interaction during its ascent, such as through channel flow from depth, as also suggested from the seismic velocity variations (Iwamori and Nakakuki 2013) and trace element transport in subduction zones (Ikemoto and Iwamori 2014). However, only a small amount of contamination by the basement granitic rocks with very high ${ }^{87} \mathrm{Sr} /{ }^{86} \mathrm{Sr}$ may have affected the $\mathrm{Sr}$ isotopic ratio of the fluid, and some crustal helium with low ${ }^{3} \mathrm{He} /{ }^{4} \mathrm{He}$ could have affected the degassed water samples such as AW-3, AW-4, and AW-5 with relatively low He content 
(Table 2). If such a fracture system is a dominant mode of fluid transport, the Arima-type brine may put direct constraints on both the compositions and processes of slab fluid at depth.

\section{Additional file}

\section{Additional file 1: Figure S1. Calculated geotherms along the}

subducting slab for southwest Japan (SW Japan) and northeast Japan (NE Japan), based on the formulation of England and Wilkins (2004), with the parameters listed in the main text.

\section{Competing interests}

The authors declare that they have no competing interests.

\section{Authors' contributions}

$\mathrm{CK}, \mathrm{HI}, \mathrm{HN}$ and $\mathrm{KK}$ designed the study, $\mathrm{CK}$ and $\mathrm{HI}$ sampled the waters and gases, CK and NM carried out the elemental and isotopic analyses, $\mathrm{CK}$ and $\mathrm{HI}$ constructed and performed numerical modeling, all authors discussed the data to make interpretation, wrote the text, prepared the figures and tables, and read and approved the final manuscript.

\section{Acknowledgements}

The authors would like to thank HA Takahashi, M Takahashi, M Tanimizu, and T Ishikawa for their help in elemental and isotopic analyses, M Totani for his kind arrangement and assistance in sampling hot spring waters in the Arima area, and the two anonymous referees for constructive review that greatly improved the manuscript.

\section{Author details}

126-1 Yamanokuchi Chitosecho-chitose, Kameoka, Kyoto 621-0002, Japan. ${ }^{2}$ Department of Solid Earth Geochemistry, Japan Agency for Marine-Earth Science and Technology (JAMSTEC), 2-15 Natsushima-cho, Yokosuka 237-0061, Japan. ${ }^{3}$ Department of Earth and Planetary Sciences, Tokyo Institute of Technology, 2-12-1 Ookayama, Meguro-ku, Tokyo 152-8551, Japan. ${ }^{4}$ Geological Survey of Japan, National Institute of Advanced Industrial Science and Technology (AIST), 1-1-1 Higashi, Tsukuba 305-8567, Japan.

Received: 3 June 2014 Accepted: 19 August 2014

Published: 19 September 2014

\section{References}

Aizawa Y, Tatsumi Y, Yamada H (1999) Element transport by dehydration of subducted sediments: implication for arc and ocean island magmatism. Island Arc 8:38-46

Arai T (2007) Geochemical characteristics of whole rock and minerals from the Late Cretaceous granitic rocks of the Rokko Mountains. J Mineral Petrol Sci 102:12-23

Birck JL (1986) Precision K-Rb-Sr isotopic analysis: application to Rb-Sr chronology. Chem Geol 56:73-83

Brenan JM, Shaw HF, Ryerson FJ, Phinney DL (1995) Mineral-aqueous fluid partitioning of trace elements at 900_C and 2.0 GPa: constraints on the trace element chemistry of mantle and deep crustal fluids. Geochim Cosmochim Acta 59:3331-3350

Edmunds WM, Kay RLF, McCartney RA (1985) Origin of saline groundwaters in the Carnmenellis granite (Cornwall, England): natural processes and reaction during hot dry rock reservoir circulation. Chem Geol 49:287-301

England P, Wilkins C (2004) A simple analytical approximation to the temperature structure in subduction zones. Geophys J Int 159:1138-1154

Fischer TP (2008) Fluxes of volatiles $\left(\mathrm{H}_{2} \mathrm{O}, \mathrm{CO}_{2}, \mathrm{~N}_{2}, \mathrm{Cl}, \mathrm{F}\right)$ from arc volcanoes. Geochem J 42:21-38

Giggenbach WF (1992) Isotopic shifts in waters from geothermal and volcanic systems along convergent plate boundaries and their origin. Earth Planet Sci Lett 113:495-510

Graham CM, Harmon RS, Sheppard SMF (1984) Experimental hydrogen isotope studies-hydrogen isotope exchange between amphibole and water. Am Miner 69:128-138
Hasegawa A, Nakajima J, Kita S, Tsuji Y, Nii K, Okada T, Matsuzawa T, Zhao D (2008) Transportation of $\mathrm{H}_{2} \mathrm{O}$ in the NE Japan subduction zone as inferred from seismic observations. J Geophys Res 117:59-75 (in Japanese with English abstract)

Hirose F, Nakajima Jl, Hasegawa A (2008) Three-dimensional seismic velocity structure and configuration of the Philippine Sea slab in southwestern Japan estimated by double-difference tomography. J Geophys Res 113, B09315, doi: 10.1029/2007JB005274

Hyndman RD, Peacock SM (2003) Serpentinization of the forearc mantle. Earth Planet Sci Lett 212:417-432

Ikemoto A, Iwamori H (2014) Numerical modeling of trace element transportation in subduction zones: implications for geofluid processes. Earth Planets Space 66:26, doi: 10.1186/1880-5981-66-26

Ionov DA (2010) Petrology of mantle wedge lithosphere: new data on suprasubduction zone peridotite xenoliths from the Andesitic Avacha Volcano, Kamchatka. J Petrol 51:327-361

Ishikawa T, Nakamura E (1992) Origin of the slab component in arc lavas from across-arc variation of B and Pb isotopes. Nature 370:205-208

Ishimaru S, Arai S (2008) Arsenide in a metasomatized peridotite xenolith as a constraint on arsenic behavior in the mantle wedge. Am Mineral 93:1061-1065

Iwamori $\mathrm{H}$ (1998) Transportation of $\mathrm{H}_{2} \mathrm{O}$ and melting in subduction zones. Earth Planet Sci Lett 160:65-80

Iwamori $\mathrm{H}$ (2007) Transportation of $\mathrm{H}_{2} \mathrm{O}$ beneath the Japan arcs and its implications for global water circulation. Chem Geol 239:182-198

Iwamori H, Albarède F (2008) Decoupled isotopic record of ridge and subduction zone processes in oceanic basalts by independent component analysis. Geochem Geophys Geosys 9: doi: 10. 2007 GC001753

Iwamori H, Nakakuki T (2013) Fluid processes in subduction zones and water transport to the deep mantle. In: Karato S (ed) Physics and chemistry of the deep earth. Elsevier, Amsterdam, pp 446-468

Jarrard RD (2003) Subduction fluxes of water, carbon dioxide, and potassium. Geochem Geophys Geosys 4:8905, doi: 10.1029/2002GC000392

Kasahara J (2003) The role of water in earthquake generation. In: Kawamura K, Kasahara J (eds) Toriumi M. University of Tokyo Press, Tokyo

Kawahata H, Kusakabe M, Kikuchi Y (1987) Strontium, oxygen, and hydrogen isotope geochemistry of hydrothermally altered and weathered rocks in DSDP Hole 504B, Costa Rica Rift. Earth Planet Sci Lett 85:343-355

Kawamoto T, Yoshikawa M, Kumagai Y, Mirabueno MHT, Okuno M, Kobayashi T (2013) Mantle wedge infiltrated with saline fluids from dehydration and decarbonation of subducting slab. Proc Natl Acad Sci U S A 110:9663-9668

Kazahaya $\mathrm{K}$ (1997) Discharged $\mathrm{H}_{2} \mathrm{O}$ from active island arc volcanoes: origin and flux. J Jpn Assoc Hydrol Sci 27:105-116

Kendrick MA, Scambelluri M, Honda M, Phillips D (2011) High abundances of noble gas and chlorine delivered to the mantle by serpentinite subduction Nature Geo 4:, doi: 10.1038/NGEO1270

Keppler H (1996) Constraints from partitioning experiments on the composition of subduction-zone fluids. Nature 380:237-240

Kessel R, Schmidt MW, Ulmer P, Pettke T (2005) Trace element signature of subduction-zone fluids, melts and supercritical liquids at 120-180 km depth. Nature 437:724-727, doi: 10.1038/nature03971

Kimura JI, Hacker BR, van Keken PE, Kawabata H, Yoshida T, Stern RJ (2009) Arc Basalt Simulator version 2, a simulation for slab dehydration and fluid-fluxed mantle melting for arc basalts: modeling scheme and application. Geochem Geophys Geosys 10, Q09004, doi: 10.1029/2008GC002217

Kogiso T, Tatsumi Y, Nakano S (1997) Trace element transport during dehydration processes in the subducted oceanic crust: 1. Experiments and implications for the origin of ocean island basalts. Earth Planet Sci Lett 148:193-205

Kozuki J (1962) Studies of Arima Spa. Nippon Shoin, Tokyo (in Japanese)

Marty B, Jambon A (1987) C/ ${ }^{3}$ He in volatile fluxes from the solid Earth: implications for carbon geodynamics. Earth Planet Sci Lett 83:16-26

Masuda H, Sakai H, Chiba H, Tsurumaki M (1985) Geochemical characteristics of $\mathrm{Na}-\mathrm{Ca}-\mathrm{Cl}-\mathrm{HCO}_{3}$ type waters in Arima and its vicinity in the western Kinki district, Japan. Geochem J 19:149-162

Matsubaya O (1981) Origin of hot spring waters based on hydrogen and oxygen isotopic ratios. Hot Spring Sci 31:47-56 (in Japanese)

Matsubaya O, Sakai H, Kusachi I, Satake H (1973) Hydrogen and oxygen isotopic ratios and major element chemistry of Japanese thermal water systems. Geochem J 7:123-151

Matsuhisa Y (1992) Origin of magmatic waters in subduction zones: stable isotopic constraints. Rept Geol Surv Japan 279:104-109 
Matsumoto T, Kawabata T, Matsuda J, Yamamoto K, Mimura K $(2003){ }^{3} \mathrm{He} /{ }^{4} \mathrm{He}$ ratios in well gases in the Kinki district, SW Japan: surface appearance of slab-derived fluids in a non-volcanic area in Kii Peninsula. Earth Planet Sci Lett 216:211-230

Matsuo S, Suzuoki T, Kusakabe M, Wada H, Suzuki M (1974) Isotopic and chemical compositions of volcanic gases from Satsuma-Iwojima, Japan. Geochem J 8:165-173

Matthews A, Goldsmith JR, Clayton RN (1983) Oxygen isotope fractionation between zoisite and water. Geochim Cosmochim Acta 47:645-654

Mazzini A, Svensen H, Etiope G, Onderdonk N, Banks D (2011) Fluid origin, gas fluxes and plumbing system in the sediment-hosted Salton Sea Geothermal System (California, USA). J Volcanol Geotherm Res 205:67-83

Mizutani Y (1978) Isotopic composition of volcanic steam from Showashinzan Volcano, Hokkaido, Japan. Geochem J 12:57-63

Morikawa N, Kazahaya K, Masuda H, Ohwada M, Nakama A, Nagao K, Sumino H (2008) Relationship between geological structure and helium isotopes in deep groundwater from the Osaka Basin: application to deep groundwater hydrology. Geochem J 42:61-74

Muehlenbachs K (1986) Alternation of the oceanic crust and the ${ }^{18} \mathrm{O}$ history of seawater. Rev Mineral 16:425-444

Nagao K, Takaoka N, Matsubayashi O (1981) Rare gas isotopic compositions in natural gases in Japan. Earth Planet Sci Lett 53:175-188

Nakajima J, Hasegawa A (2007) Subduction of the Philippine Sea slab beneath southwestern Japan: slab geometry and its relationship to arc magmatism. J Geophys Res 112, B08306, doi: 10.1029/2006JB004770

Nakamura H, Iwamori H (2009) Contribution of slab fluid in arc magmas beneath the Japan arcs. Gondwana Res 16:431-445, doi: 10.1016/j.gr.2009.05.004

Nakamura H, Iwamori H (2013) Generation of adakites in a cold subduction zone due to double subducting plates. Contrib Mineral Petrol 165:1107-1134, doi: 10.1007/s00410-013-0850-0

Nakamura H, Iwamori H, Kimura JI (2008) Geochemical evidence for enhanced fluid flux due to overlapping subducting plates. Nature Geo 1:380-384

Nakamura H, Fujita Y, Nakai S, Yokoyama T, Iwamori H (2014) Rare earth elements and $\mathrm{Sr}-\mathrm{Nd}-\mathrm{Pb}$ isotopic analyses of the Arima hot spring waters, Southwest Japan: implications for origin of the Arima-type brine. J Geol Geosci 3:161 doi: 10.4172/2329-6755.1000161

Nishimura S (2000) Forearc volcanism and hot-springs in Kii Peninsula, Southwest Japan. Hot Spring Sci 49:207-216 (in Japanese with English abstract)

Nissenbaum A, Presley BJ, Kaplan IR (1972) Early diagenesis in a reducing fjord, Saanich Inlet, British Columbia - I. Chemical and isotopic changes in major components of interstitial water. Geochim Cosmochim Acta 36:1007-1104

O'Neil JR (1986) Stable isotopes in high temperature geological processes. Rev Mineral 16:1-40

Okada T, Itaya T, Sato M, Nagao K (1994) Noble gas isotopic composition of deep underground water in Osaka plain, central Japan: evidence for mantle He and model for new volcanism. Island Arc 3:221-231

Okino K, Shimakawa Y, Nagaoka S (1994) Evolution of the Shikoku Basin. J Geomagn Geoelectr 46:463-479

Pearce JA, Stern RJ, Bloomer SH, Fryer P (2005) Geochemical mapping of the Mariana arc-basin system: implications for the nature and distribution of subduction components. Geochem Geophys Geosys 6, Q07006, doi: 10.1029/ 2004GC000895

Plank T, Langmuir CH (1998) The chemical composition of subducting sediment and its consequences for the crust and mantle. Chem Geol 145:325-394

Poreda R (1985) Herium-3 and deuterium in back-arc basalts: Lau Basin and the Mariana Trough. Earth Planet Sci Lett 73:244-254

Sakai H, Matsubaya O (1977) Stable isotopic studies of Japanese geothermal systems. Geothermics 5:97-124

Sakai H, Matsuhisa Y (1996) Stable isotope geochemistry. University of Tokyo Press, Tokyo, 403 pp; (in Japanese)

Sano Y, Marty B (1995) Origin of carbon in fumarolic gas from island arcs. Chem Geol 119:265-274

Sano Y, Wakita H (1985) Geographical distribution of ${ }^{3} \mathrm{He} /{ }^{4} \mathrm{He}$ ratios in Japan - implications for arc tectonics and incipient magmatism. J Geophys Res 90:8729-8741

Sano Y, Kameda A, Takahata N, Yamamoto J, Nakajima J (2009) Tracing extinct spreading center in SW Japan by helium-3 emanation. Chem Geol 266:50-56, doi: 10.1016/j.chemgeo.2008.10.020

Schiano P, Clocchiatti R, Shimizu N, Maury RC, Jochum KP, Hofmann AW (1995) Hydrous silica-rich melts in the sub-arc mantle and their relationship with erupted arc lavas. Nature 377:595-600
Schmidt MW, Poli S (1998) Experimentally based water budgets for dehydrating slabs and consequences for arc magma generation. Earth Planet Sci Lett 163:361-379

Schmitt AK, Martín A, Weber B, Stockli DF, Zou H, Shen C-C (2013) Oceanic magmatism in sedimentary basins of the northern Gulf of California rift. Geol Soc Am Bull 125:1833-1850, doi: 10.1130/B30787.1

Shaw AM, Hauri EH, Fischer TP, Hilton DR, Kelley KA (2008) Hydrogen isotopes in Mariana arc melt inclusions: implications for subduction dehydration and the deep-Earth water cycle. Earth Planet Sci Lett 275:138-145

Shilobreeva S, Martinez I, Busigny V, Agrinier P, Laverne C (2011) Insights into C and $\mathrm{H}$ storage in the altered oceanic crust: results from ODP/IODP Hole 1256D. Geochim Cosmochim Acta 75:2237-2255

Shinohara H (2013) Volatile flux from subduction zone volcanoes: insights from a detailed evaluation of the fluxes from volcanoes in Japan. J Volcanol Geotherm Res 268:46-63

Straub SM, Layne GD (2003) The systematics of chlorine, fluorine, and water in Izu arc front volcanic rocks: implications for volatile recycling in subduction zones. Geochim Cosmochim Acta 67:4179-4203

Suzuoki T, Epstein S (1976) Hydrogen isotope fractionation between $\mathrm{OH}$-bearing minerals and water. Geochim Cosmochim Acta 40:1229-1240

Takahashi HA, Nakamura T, Tsukamoto H, Kazahaya K, Handa H, Hirota A (2013) Radio carbon dating of groundwater in granite fractures in Abukuma Province, northeast Japan. Radio Carbon 55:894-904

Tanaka K, Koizumi M, Seki R, Ikeda N (1984) Geochemical study of Arima hot-spring waters, Hyogo, Japan, by means of tritium and deuterium. Geochem J 18:173-180

Taran YA, Pokrovsky BG, Dubik YM (1989) Isotopic composition and the origin of water from andesitic magmas. Trans Acad Sci USSR 304:440-443

Taran YA, Varley NR, Inguaggiato S, Cienfuegos E (2010) Geochemistry of $\mathrm{H}_{2}$ - and $\mathrm{CH}_{4}$-enriched hydrothermal fluids of Socorro Island, Revillagigedo Archipelago, Mexico. Evidence for serpentinization and abiogenic methane. Geofluids 10:542-555, doi: 10.1111/j.1468-8123.2010.00314.x

Terakado Y, Nohda S (1993) Rb-Sr dating of acidic rocks from the middle part of the Inner Zone of southwest Japan: tectonic implications for the migration of the Cretaceous to Paleogene igneous activity. Chem Geol 109:69-87

Umeda K, Ogawa Y, Asamori K, Oikawa T (2006) Aqueous fluids derived from a subducting slab: observed high ${ }^{3} \mathrm{He}$ emanation and conductive anomaly in a nonvolcanic region, Kii Peninsula southwest Japan. J Volcanol Geotherm Res 149:47-61

Wenner DB, Taylor HP (1971) Temperatures of serpentinization of ultramafic rocks based on $0^{18} / \mathrm{O}^{16}$ fractionation between coexisting serpentine and magnetite. Contrib Mineral Petrol 32:165-185

White DE (1957) Magmatic, connate, and metamorphic waters. Geol Soc Am Bull 68:1659-1682

You CF, Castillo PR, Gieskes JM, Chan LH, Spivack AJ (1996) Trace element behavior in hydrothermal experiments: implications for fluid processes at shallow depths in subduction zones. Earth Planet Sci Lett 140:41-52

Zelenski ME, Taran YA, Dubinina EO, Shapar VN, Polyntseva EA (2012) Sources of volatiles for a subduction zone volcano: Mutnovsky Volcano, Kamchatka. Geochem Int 50:502-521

Zheng YF, Metz P, Satir M (1994) Oxygen-isotope fractionation between calcite and tremolite-an experimental study. Contrib Mineral Petrol 118:249-255

\section{doi:10.1186/1880-5981-66-119}

Cite this article as: Kusuda et al:: Arima hot spring waters as a deep-seated brine from subducting slab. Earth, Planets and Space 2014 66:119. 